\title{
Anthracnose of Capsicum annuum L. (Chilli)
}

\author{
Raghavendra Reddy Manda ${ }^{1}$, G. Pavithra ${ }^{1}$, \\ Venkata Avinash Addanki ${ }^{2}$ and Seweta Srivastava ${ }^{*}$
}

${ }^{1}$ School of Agriculture, Lovely Professional University, Phagwara - 144 411, Punjab, India

${ }^{2}$ Department of Agronomy, Food, Natural Resources, Animals and the Environment, University of Padua, Padova - 35122, Italy

*Corresponding author

\section{A B S T R A C T}

\section{Keywords}

Chilli, Anthracnose, Colletotrichum annuum,

Management, Bioagents, Fungicides

Article Info

\section{Accepted:}

07 October 2020

Available Online:

10 November 2020
Capsicum annuum (Chilli) is an important spice crop grown in tropical and subtropical areas. India is the global leader in production of chilli. Several biotic \& abiotic constraints severely affect the yield of chilli. Among the biotic constraints the plant diseases play a vital role in the crop loss. Chilli is effected by several diseases, out of which anthracnose of chilli is one of the important disease. It is also termed as dieback or fruit rot. It is caused by Colletotrichum capsici. This devastating pathogen damages both immature and mature fruits reducing the nutritive and marketing value of chillies. This review article focuses on the nature of pathogen, symptomology and effective management techniques used for eliminating anthracnose of chilli.

\section{Introduction}

Capsicum annuum (Chilli) is an important spice crop grown in tropical and subtropical areas. It belongs to the family Solanaceae. India is the global leader in the production of chilli. The fruits of chilli are considered as vegetable and botanically called as berries (Saxena et al., 2016).

\section{Importance of chilli}

India is the only one source for hot chillies. In India chillies are used as principle ingredient in various curries and chutneys. It is also used for vegetables, spices, condiments, sauces and pickle. It is widely used for its pungency and pleasant flavor. The capsaicin which is alkaloid present in the placenta and pericarp of the chilli fruits is the reason behind the pungency in chilli. In addition to the fact that it is utilized in numerous cooking styles it is found to have numerous therapeutic properties An experimental study shows that the capsaicin has anti-diabetic, anti-bacterial, analgesic and anti- carcinogenic properties (Geetha and Selvarani, 2017). Furthermore, chilli will decrease the cancer rate through 
prohibiting carcinogens attachment with DNA and decrease the calorie intake through increasing thermogenesis. Fresh chillies are rich in proteins, minerals, vitamin $\mathrm{A}$ and $\mathrm{C}$. Whereas dried chillies are rich in Vitamin A and D. Chillies are also having other antioxidants that are vitamin-A and flavonoids which includes $\alpha$-carotene, $\beta$ carotene, zeaxanthin, lutein and cryptoxanthin. They are also good source of other antioxidants such as vitamin-A and flavonoids.

\section{Constraints in chilli production}

Being an important spice crop grown worldwide, there decreased production is due to biotic and abiotic constraints which significantly lead to the yield loss and seed production. Some of the biotic constraints are plant disease which play major role in crop losses. The plant disease is caused by fungi, bacteria, viruses or nematodes affect the chilli production in many parts of world (Saxena et al., 2016). Chilli is usually affected by fungal diseases like anthracnose (dieback/fruit rot), Cercospora leaf spot, Damping off, Wilt, Leaf spots, Powdery mildew, Bacterial diseases like Bacterial Wilt, Soft rot and Some viral diseases like Cucumber Mosaic Virus (CMV), Tomato Spotted Wilt Virus (TSWV), Tobacco Mosaic Virus (TMV), etc. (Than et al., 2008).

\section{Historical ssignificance of anthracnose}

Anthracnose was reported for the first time in Coimbatore of Madras Presidency - India (Sydow, 1913). The losses due to the impact of chilli anthracnose are estimated to be $50 \%$ in different parts of India (Pakdeevaraporn et al., 2005). The average disease incidence level ranges between $66-84 \%$ and results in yield loss upto 12-50\% (Thind and Jhooty, 1985). The disease was accounted to cause yield losses of 8-27\% in Maharashtra, 20-60\% in Punjab and Haryana and 30\%-76\% in Tamil Nadu (Bansal and Grover, 1969).

\section{The pathogen}

The pathogen responsible for anthracnose disease is induced by several Colletotrichum Species: which comes under the FamilyGlomerellaceae; Order- Glomerellsles; ClassSordariomycetes; Phylum-Ascomycota; Kingdom-Fungi (Agrios, 2005). The perfect stage was identified as Glomerella. Anthracnose disease has been induced by several species of Colletotrichum which includes $C$. acutatum, $C$. coccodes, $C$. gleosporioides, $C$. atramentarium, $C$. dematium and $C$. capsici (Gopinath et al., 2006). There is an enormous variation among species of Colletotrichum causing anthracnose disease. Between the species already present, $C$. capsici / $C$. truncatum is a cosmopolitan fungus. In India Colletotrichum capsici is most prevalent in ripen chilli where Colletotrichum acutatum and Colletotrichum gloeosporioides induce disease in green and red chilli (Than et al., 2008).

\section{Disease incidence and transmission}

Chilli anthracnose is seed and air borne disease and has a greater effect on seed germination and its vigour (Saxena et al., 2016). The favorable temperature for the disease is $27^{\circ} \mathrm{C}$ with relative humidity $80 \%$ and a soil pH 5-6 (Roberts et al., 2001). It damages the crop right from the early stage and continues till harvest. Hot and humid conditions are favorable for transmission of this disease.

Chilli anthracnose is a polycyclic pathogen, where the initial disease is induced by the spores of Colletotrichum capsici which survive in and on seed in the form of acervuli and microsclerotia (Montri et al., 2009). The spores disseminate, deposit and germinate on 
the surface of the chilli plants. From appressoria the germinating spore penetrate into the cuticle layer of plant and produce the infectious hyphae results in development of lesions (Yu et al., 2013).

\section{Symptomology of anthracnose disease in chilli}

The disease symptoms appears on leaves, stem and also on the fruits. In nurseries, most common symptom is damping-off or seedling blight. At various stages of growth die back and leaf spotting occurs in plant. Die back symptom begins from the tip of the plants branches and finally reach downwards results in the progressive death of the branch. Rotting and fruit spotting occurs in ripe chilli with formation of acervuli in concentric rings, sunken necrotic tissues and coalesced lesion (Siddiqui et al., 1977).

\section{Symptoms on leaves}

The symptoms appear on the leaves as small brown or black water soaked spots which are surrounded by light brown or yellow hallow margin. These spots were small at first, develop larger and get coalesced with each other to form a large lesion. These lead to necrotic spot and at later stages defoliation of leaves takes place from the crop (Fig. 1).

\section{Symptoms on stem}

Initial symptoms on the stem were brown spots leads to necrosis of twigs which finally ends up in die back of the plants at severe situation. Acervuli were found on the necrotic surface of the twigs (Fig. 2).

\section{Symptoms on fruits}

In fruits the initial symptoms were water soaked lesion on the surface of fruits which leads to necrotic tissue formation and further develops into elliptical spot. The lesion turned into concentric rings and the black pin head size acervuli are seen on the concentric lesion. Conidial mass also occurs on severe stage. The fruit become wrinkled, deformed, shriveled and dried when it is affected completely (Fig. 3).

\section{Identification of the pathogen}

Colletotrichum spp. can be identified from studies of Kulshrestha et al., (1976) and Desai and Prasad (1955).

\section{Colony character}

When grows on plates its colony morphology can be observed with white to grey, a dark green center, and dense, filamentous mycelium (Than et al., 2008). It takes 5-7 days for completing the mycelial growth in $9 \mathrm{~cm}$ diameter Petri plate

\section{Conidia}

Consists of hooked shaped conidia produced from acervuli, a subepidermal fruiting body (Than et al., 2008).

\section{Fruiting body}

The fungus produces black colored acervuli with disc shaped with dark needle like setae. The setae were dark brown to black color.

\section{Disease management}

No single management techniques have found to be effective against this disease. Integrated usage of physical, biological and chemical control has been recommended for effective management of this disease (Agrios, 2005).

Cultural practices: These are the precautionary measures. They are implemented to reduce the rate of infection 
and minimize the inoculum pressure (Kiran et al., 2020). As this pathogen is seed, air and water borne the cultural practices should focus on various cultural practices (Than et al., 2008 and Ali et al., 2016).

Crop rotation - rotation of chillies with other crops for which Colletotrichum is not an alternative host for a span of $2-3$ years (Roberts et al., 2001)
Proper drainage - There should be the proper drainage system to channelize the wate water out of the field because the conidia of the pathogen will easily spread from the infected plant to the non-infected plant through water splashes. Moreover relative humidity helps in successful colonization of the pathogen.

Weeding - Weeds should be eliminated from the area of sowing or transplanting.

Fig.1

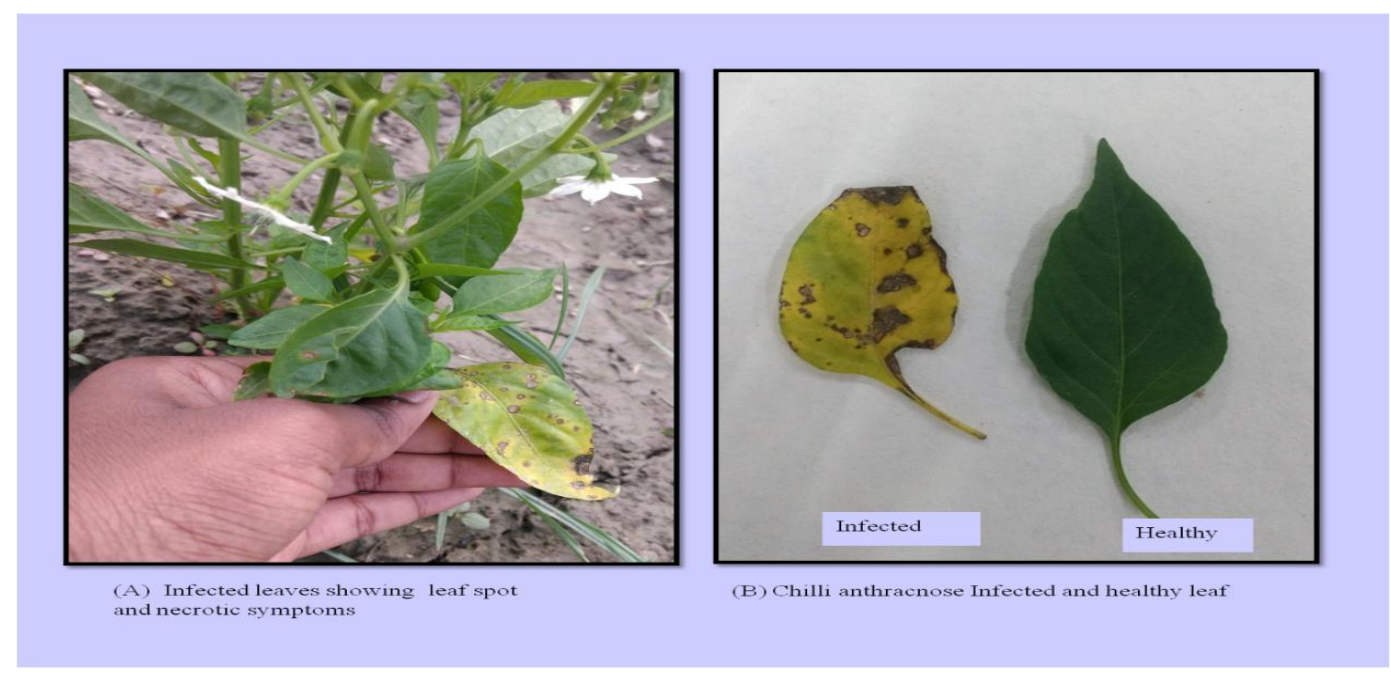

Fig.2

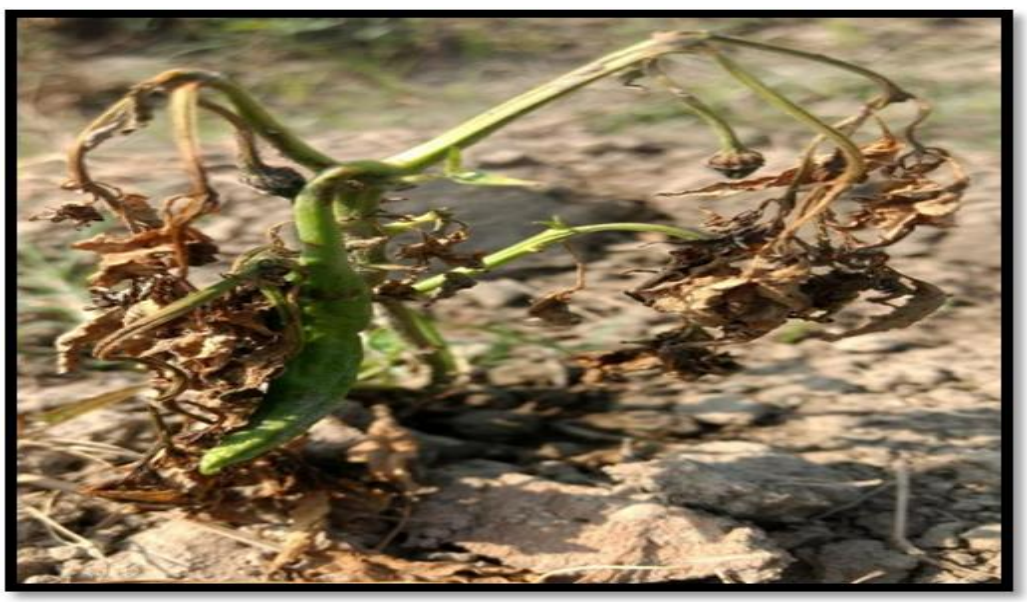


Fig.3

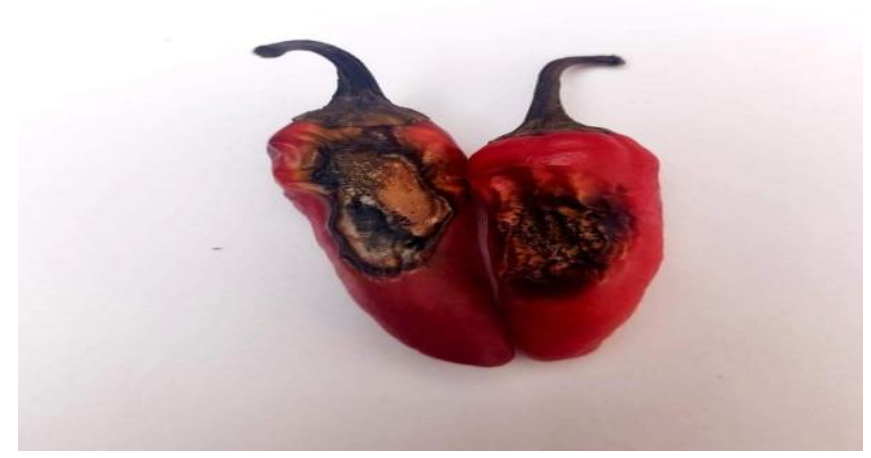

Usage of disease free seeds - Disease free seeds should be used to raise the chilli seedlings in the nursery or field.

Mulching - Utilisation of plastic mulches and rice straw has been reported to control this disease effectively (Vos et al., 1995)

Deep ploughing - Deep ploughing at the end of the season can help in removing the infected crop debris from the field or cover the diseased plants deep into the soil (Sharma et al., 2015)

Usage of resistant varieties - Two varieties (Tanjung-2 and Lembang1) from Indonesian Vegetables Research Center were proved to be moderately resistant (Setiawati et al., 2008) and Five Varieties (AVPP0207, AVPP0513, AVPP0719, AVPP1004-B, AVPP1102-B) from World Vegetables Center, Taiwan reported to have tolerance to anthracnose (Hasyim et al., 2014).

\section{Biological control}

Trichoderma spp. are widely applied for controlling Colletotrichum spp.in chilli (Boonratkwang et al., 2007 and Singh et al., 2007). They compete with the pathogen to occupy more surface area which in turn reduces the infection successfully (Kashyap et al.2017; Maymon et al., 2004 and Jeffries et al., 1992). Pseudomonas fluorescens can also be used to control the anthracnose. Trichoderma is well known saprophytic fungus which has a very wider adaptability. The biological control potential of Trichoderma is very well established against some devastating plant pathogens like Colletotrichum, Alternaria, Pythium, Phytophthora, Rhizoctonia, etc. (Singh et al., 2012; Jain et al., 2012; Imtiaj and Lee, 2008 and Begum et al., 2008). The mechanisms that are involved are antibiosis, competition for nutrients and space and mycoparasitism (Hermosa et al., 2012; Shoresh et al., 2010 and Harman, 2006).

\section{Chemical control}

Out of various control methods, chemical control is regarded as the most effective (Akhtar, 2007). As the time required for giving the result is less, utilization of fungicides to control anthracnose has been more popularised (Wharton and DiéguezUribeondo, 2004). Relying on one single fungicide is not good, because continuous usage of a particular fungicide results in development of resistance (Staub, 1991). Maneb (Manganese ethylenebisdithiocarbamate) is traditionally the most recommended fungicide for the control of 
anthracnose (Smith, 2000). Timely application of fungicides is very important. Other fungicides such as Mancozeb (0.2\%), Ziram (0.1\%), Copper oxy chloride and Bordeaux mixture $(0.5$ or $1 \%)$ were also found effective. Difenoconazole $(0.025 \%)$ was significantly superior over rest of the fungicides (Propiconazole, copper oxychloride and Carbendazim + Mancozeb), which was recorded the minimum disease intensity of 21.13 per cent with highest fruit yield (Katedia et al., 2019).

Dubey et al., 2019 evaluated Five fungicides viz. Kasugamycin (Kasu B 3\%SL), Pyraclostrobin + Metaram (Carbrio Top 60\%WG), Azoxystrobin (Onestar 23\%SC), Fusilazole (Cursor 40\%EC) and Folicur 250 EC (Tebuconazole) for their efficacy against Colletotrichum capsici by Poison food technique. These fungicides were prepared at two concentrations viz. $250 \mathrm{ppm}$ and 500ppm. Cabrio Top with per cent inhibition of $84.11 \%$ found to be best in inhibiting mycelia growth of pathogen and found to be superior over other chemical fungicides.

In conclusion, as chilli is an important spice crop. The devastating diseases such as Anthracnose should be counteracted effectively for increasing its marketability and consumption. This is only possible if one can easily detect, diagnose and manage the disease. As this disease is most prevailing and common the scientific community should develop integrated management approaches, as a step towards sustainability in agricultural production.

\section{References}

Agrios GN. Plant Pathology. 5th Ed. San Diego: Academic Press; 2005. p. 922.

Akhtar J. Effect of fungicides on growth and sensitivity of the isolates of Colletotrichum capsici causing fruit rot of chilli. Journal of Plant Disease Sciences. 2007; 2(1): 59-62.

Ali A, Bordoh PK, Singh A, Siddiqui Y, Droby S. (2016) Post-harvest development of anthracnose in pepper (Capsicum spp): Etiology and management strategies. Crop Protection.90, 132-141.

Bansal RD, Grover RK. (1969) Reaction of chilli (Capsicum frutescens) varieties to Colletotrichum capsici. Punjab Agr Univ J Res. (agris.fao.org)

Begum, M. M., Sariah, M., Abidin, Z. M. A., Puteh, B. A., and Rahman, A. M. (2008). Antagonistic potential of selected fungal and bacterial biocontrol agents against Colletotrichum truncatum of soybean seeds. Pertanica J. Trop. Agric. Sci. 31, 45-53.

Boonratkwang $\mathrm{C}$, Chamswarng $\mathrm{C}$, Intanoo W, Juntharasri V. (2007). Effect of secondary metabolites from Trichoderma harzianum strain Pm9 on growth inhibition of Colletotrichum gloeosporioides and chilli anthracnose control. In: Proceeding of the $8^{\text {th }}$ National Plant Protection Conference. Phisanulok, Thailand: Naresuan University; pp. 323-336.

Desai MV, Prasad N. (1955). A new Colletotrichum from India. Indian Phytopath.8(1),52-7.

Dubey P, Chandra R, Gupta P. (2019) Effect of different fungicides against Colletotrichum capsici caused chilli anthracnose disease. (thepharmajournal.com)

Geetha R, Selvarani K. (2017). A study of chilli production and export from India. International Journal of Advance Research and Innovative Ideas in Education. 3(2),205-10.

Gopinath K, Radhakrishnan NV, Jayaraj J. (2006) Effect of propiconazole and difenoconazole on the control of anthracnose of chilli fruits caused by 
Colletotrichum capsici. Crop Protection. 25(9),1024-31.

Harman, G.E. (2006) Overview of mechanisms and uses of Trichoderma spp. Phytopathology 96, 190-194.

Hasyim A, Setiawati W, Sutarya R. (2014). Screening for resistance to anthracnose caused by Colletotrichum acutatum in chili pepper (Capsicum annuиm L.) in Kediri, East Java. Advances in Agriculture \& Botanics. 6(2),104-118

Hermosa, R., Viterbo, A., Chet, I., and Monte, E. (2012). Plant-beneficial effects of Trichoderma and of its genes. Microbiology 158, 17-25.

Imtiaj, A., and Lee, S. T. (2008). Antagonistic effect of three Trichoderma species on the Alternaria porri pathogen of onion blotch. World J. Agric. Sci. 4, 13-17.

Jain, A., Singh, S., Sarma, B. K., and Singh, H. B. (2012). Microbial consortium mediated reprogramming of defence network in pea to enhance tolerance against Sclerotinia sclerotiorum. J. Appl. Microbiol. 112, 537-550.

Jeffries P, Koomen I. (1992) Strategies and prospects for biological control of diseases caused by Colletotrichum. In: Strategies and Prospects for Biological Control of Diseases Caused by Colletotrichum. Wallingford: Commonwealth Mycological Institute; pp. 337-357

Kashyap PL, Rai P, Srivastava AK, Kumar S. (2017) Trichoderma for climate resilient agriculture. World Journal of Microbiology and Biotechnology. 33(8), 155.

Katediya MA, Jaiman RK, Kumar S. (2019). Management of chilli anthracnose caused by Colletotrichum capasici. Journal of Pharmacognosy and Phytochemistry. 8(3), 2697-701.

Kiran R, Akhtar J, Kumar P, Shekhar M. (2020) Anthracnose of Chilli: Status, Diagnosis, and Management. In:
Capsicum . IntechOpen.

Kulshrestha, D.D., Mathur, S.B. and Neegard, P. (1976). Identification of seed borne species of Colletotrichum. Friesia, 11,116-125. (Contribution No. 56, Danish Government Institute of Seed Pathology for Developing Countries, Copenhagen, Denmark).

Maymon M, Minz D, Barbul O, Zveibil A, Elad Y, Freeman S. (2004). Identification of Trichoderma biocontrol isolates to clades according to ap-PCR and ITS sequence analyses. Phytoparasitica. 32(4), 370-3755.

Montri P, Taylor PW, Mongkolporn O. (2009). Pathotypes of Colletotrichum capsici, the causal agent of chili anthracnose, in Thailand. Plant Disease. 93(1), 17-20.

Pakdeevaraporn P, Wasee S, Taylor PW, Mongkolporn O. (2005). Inheritance of resistance to anthracnose caused by Colletotrichum capsici in Capsicum. Plant Breeding. 124(2), 206-208.

Roberts, P. D., Pernezny, K., and Kucharek, T. A. (2001). Anthracnose Caused by Colletotrichum sp. on Pepper. University of Florida/Institute of Food and Agricultural Sciences, Available online at: http://edis.ifas.ufl.edu/PP104

Saxena A, Raghuwanshi R, Gupta VK, Singh HB. (2016). Chilli anthracnose: The epidemiology and management. Frontiers in Microbiology. 7, 1527.

Setiawati W, Udiarto BK, Soetiarso TA. (2008) The effect of variety and planting system of chili pepper on incidence of whiteflies. The Horticulture Journal. 18(1), 55-61.

Sharma M, Kulshrestha S. (2015) Colletotrichum gloeosporioides: An anthracnose causing pathogen of fruits and vegetables. Biosciences, Biotechnology Research Asia. 12(2), 1233-1246.

Shoresh, M., Harman, G. E., and Mastouri, F. 
(2010). Induced systemic resistance and plant responses to fungal biocontrol agents. Апnи. Rev. Phytopathol. 48, 21-43.

Siddiqui MR, Singh D, Gaur A. (1977). Prevalence of chilli anthracnose fungus on seeds and its effective control. Seed Research. (agris.fao.org)

Singh MK, Akhtar J, Kumar A, Khalid A. (2007). Sensitivity of different isolates of Colletotrichum capsici to Trichoderma spp. Journal of Ecofriendly Agriculture. 2(1), 54-55.

Singh, H. B., Singh, B. N., Singh, S. P., and Sarma, B. K. (2012). Exploring different avenues of Trichoderma as a potent biofungicidal and plant growth promoting candidate-an overview. Rev. Plant Pathol. 5, 315-426.

Smith, K. L. (2000). "Peppers," in Ohio Vegetable Production Guide, ed R. J. Precheur (Columbus, Ohio, OH: Ohio State University Extension), 166-173. Available online at: https://ag.purdue.edu/btny/midwestvegetable-guide/Pages/default.aspx

Staub, T. (1991). Fungicide resistance: practical experience and antiresistance strategies and the role of integrated use. Annu. Rev. Phytopathol. 29, 421-
442.

Than PP, Jeewon R, Hyde KD, Pongsupasamit S, Mongkolporn $\mathrm{O}$, Taylor PW. (2008). Characterization and pathogenicity of Colletotrichum species associated with anthracnose on chilli (Capsicum spp.) in Thailand. Plant Pathology. 57(3), 562-72.

Thind TS, Jhooty JS. (1985) Relative prevalence of fungal diseases of chilli fruits in Punjab. Indian Journal of Mycology and Plant Pathology.15(3),305-7.

Vos, J.G.M., Uhan, T.S. and Sutatya, R. (1995). Integrated crop management of hot pepper (Capsicum spp.) under tropical lowland conditions: effects of rice straw and plastic mulches on crop health. Crop Prot. 14, 445-452.

Wharton, P.S. and Diéguez-Uribeondo, J. (2004). The biology of Colletotrichum acutatum. Anal. Jardin Botan. Madrid 61, 3-22.

Yu SM, Ramkumar G, Lee YH. (2013) Light quality influences the virulence and physiological responses of Colletotrichum acutatum causing anthracnose in pepper plants. Journal of Applied Microbiology115(2),509-16.

\section{How to cite this article:}

Raghavendra Reddy Manda, G. Pavithra, Venkata Avinash Addanki and Seweta Srivastava. 2020. Anthracnose of Capsicum апnиum L. (Chilli). Int.J.Curr.Microbiol.App.Sci. 9(11): 749756. doi: https://doi.org/10.20546/ijcmas.2020.911.090 